\title{
Soil Zonation and The Shaking Table Test of The Embankment on Clayey Soil
}

\author{
Ripon Hore $^{1 *}$, Sudipta Chakraborty ${ }^{2}$, Md. Fayjul Bari ${ }^{1}$, Ayaz Mahmud Shuvon², and \\ Mehedi Ahmed Ansary ${ }^{1}$ \\ ${ }^{1}$ Department of Civil Engineering, Bangladesh University of Engineering and Technology \\ (BUET), Dhaka, 1000, Bangladesh \\ ${ }^{2}$ Bangladesh Network Office for Urban Safety (BNUS), Bangladesh University of \\ Engineering and Technology, Dhaka, 1000, Bangladesh \\ *Corresponding Author : riponhore@gmail.com
}

Received 22 March 2020/ Revised 5 June 2020 / Accepted 21 June 2020/ Available Online 28 June 2020

\begin{abstract}
The main objective of this research was to model the zonation of wrap faced embankment on soft clay foundation, by applying a shake table test. Also, to investigate the dynamic behaviors of clay soil, such as acceleration amplification, displacement and pore water pressure of wrap faced embankment. This was done with respect to changes in frequencies of $1 \mathrm{~Hz}, 3 \mathrm{~Hz}, 5 \mathrm{~Hz}, 10 \mathrm{~Hz}, 12 \mathrm{~Hz}$ and $15 \mathrm{~Hz}$ respectively. Constant acceleration $(0.1 \mathrm{~g})$ and surcharge $(19 \mathrm{Kg})$ were applied by using a laminar box, placed on a shake table testing machine. The main elements of this research were the laboratory test, which was used for preparing reconstitute soil samples, and wrap faced embankment with frequency arrangement. After applying all test parameters, dynamic parameters were increased by rise in elevation with respect to frequency. The result shows that the maximum dynamic parameters were found at the frequency of $10 \mathrm{~Hz}$. It is beneficial to the relative performances of the wrap faced embankment, which is the updated design parameter.
\end{abstract}

Keywords: Seismic; Clay Soil; Frequency; Shake Table Test; Wrap Faced; Soil Zonation

\section{Introduction}

The soil-foundation formed from soft clay becomes the focus of Seismic Engineering. In some cases, the foundation on soft clay is creating a problem for the design and construction of any type of structure. In Bangladesh, the southern part of the country, an 
excessive amount of soft clay is found in the Khulna and Bagerhat districts and also in the surroundings of Dhaka city (Hore et al., 2019). Bangladesh has the largest delta in the world. Therefore, very large alluviums are deposited on its surface. The oldest deposits are the barend, madhapur and lamaicregion clay. The sediments deposited are not evenly distributed throughout the country. At the northern part, it is about $128 \mathrm{~m}$ thick and this is where granite is extracted for construction purposes. Conversely, the thickness was gradually increased towards the south. At the centre, the capital city, Dhaka of Bangladesh has a sediment covering of over $22 \mathrm{~km}$ (Al zaman \& Jahan Monira, 2017; Alam \& Islam, 2009; Bazlar Rashid et al., 2018; Haque et al., 2013; Hore et al., 2019). Earthquakes or any seismic effects may cause a major damage on this type of soil. The earthquakes or any sinusoidal waves (railway vibration) have often created significant problems during the design and construction of the embankment. Moreover, it may be damaged due to the softening of soilfoundation (Ering \& Sivakumar Babu, 2020; Krishna \& Latha, 2007; Kumar et al., 2020; Latha \& Krishna, 2006; Zhou et al., 2020). The Soil and Structure Interaction (SSI) system was considered in this experimental study, to simulate actual soil-foundation (Bullock et al., 2019; Çelebi et al., 2019; He \& Jiang, 2019; Hore et al., 2020; Srilatha, et al., 2013; Srinivasan et al., 2016). Soft soils in Dhaka, Bangladesh were used to build the soilfoundation.

Krishna \& Latha (2007) determined the result of shake table tests on geotextilereinforced wrap faced soil-retaining walls. A total number of 9 model tests were described, such as development, experiment methodology, and outcomes. Srilatha et al., (2013) illustrated the effect of frequency of base shakes on the dynamic response of unreinforced and reinforced soil slopes. Xiao et al., (2014) investigated the earthquake response of a slurry wall and presented a minimized scale shake table test. In this research, soil-cement-bentonite (SCB) was evaluated. This is also a common type of slurry wall. Reinforced soil is only slightly damaged during the recent seismic disasters in Japan (Suzuki et al., 2015). The seismic behaviour of this soil wall is formed from clay, cement-treated clay, sand based on shake table tests and results of the pull-out. Fleming et al., (2016) conducted a contemporary phenomenon on soft clay soil, to determine the consequences of soil improvement on the seismic resistance of piles. Yazdandoust (2017) conducted a recent laboratory test to assess the character of 1-g shake table tests. Many researchers also performed a shake table test to study the seismic responses of different soil structures on soft soil (Beskhyroun et al., 2011; 
Edinçliler \& Toksoy, 2017; Hamayoon et al., 2016; Hassan \& Pal, 2018; Helwany et al., 2017; Madhavi Latha \& Manju, 2016).

Few researchers focused on shake table tests on soft clay soil in South Asian regions. In Bangladesh, there have been limited studies related to shake table tests of wrap faced retaining walls, on soft clay. Therefore, the purpose of this research was to study the effects of frequency on reinforced soil wall models. The objectives of this study were to: a) measure the response of wrap faced and reinforced soil retaining wall, which was subjected to dynamic loading through shake table; b) investigate the acceleration amplification, deformation, and pore water pressure with respect to frequency response; c) to zone the wrap faced embankment on the soft clay foundation, by applying a shake table test, and d) draw the contour maps using PLAXIS 3D Software.

\section{Methods}

\subsection{Area of Study}

The clay soil sample was collected at a depth of $1.5 \mathrm{~m}$ below the existing ground level from the Dhaka city of Bangladesh as shown in figure 1. These homogeneous, stiff, reddish brown samples were at first oven-dried. Subsequently, the dry lumps were then powdered gently by using a wooden hammer. It was finally sieved through a 200 standard sieve to obtain clean clay-like soil powder. This type of clay is very dominant in catchment areas (areas around ariver) with a thickness from 1 to $20 \mathrm{~m}$. A total number of 1000 drill holes were carried out for the Standard Penetration Test (SPT) in and around Bangladesh. Furthermore, 470 drill holes were chosen for the formation of soft clay layers.

In addition, a map identified with zoning for SPT values were from 1 to 5. The total area was divided into five subsections according to the thickness of soft clay soil. The lower range of soft clay thickness is 0 to 1 and the higher range is between 10 to 20 . From the thickness map and bore log, SPT N zone was realized. The target of this study was to obtain the accuracy of the seismic design of roadway and rail sub structure, based on the aforementioned necessities. On this model embankment, 100 shake table tests were experimented. The analysis implemented a repeated loading and unloading process. 


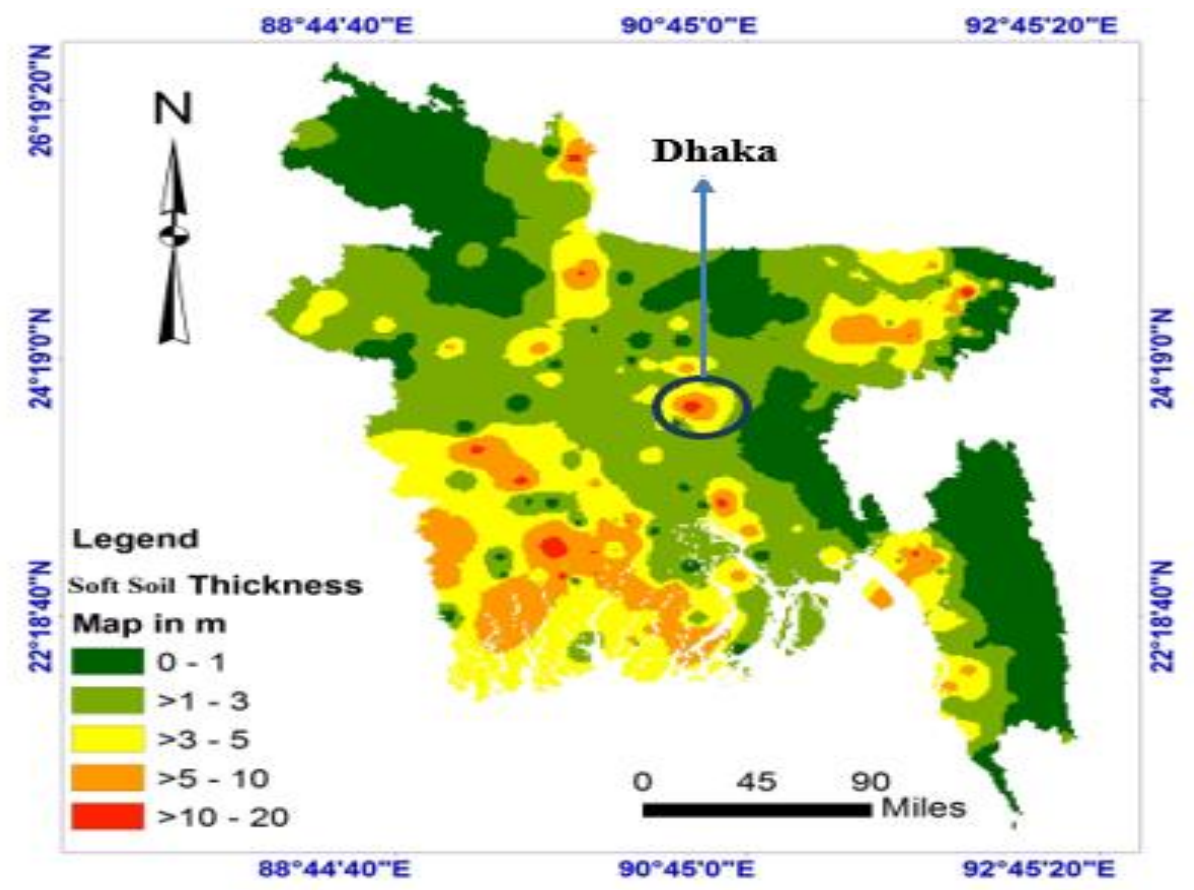

Figure 1. Study area and the thickness map for Soft soil in Bangladesh

\subsection{Using Equipment and Materials}

The shake table facility, which is computer-controlled, was used to simulate the horizontal shake action associated with dynamics. The platform of testing was a square, with a dimension of $2.5 \times 2.5 \mathrm{~m}^{2}$ and an approximate payload capacity of $1100 \mathrm{~kg}$, made up of steel plates. The range of acceleration is $0.05 \mathrm{~g}$ to $2 \mathrm{~g}$. The frequency range is 0.05 to $50 \mathrm{~Hz}$ with a maximum amplitude of $\pm 200 \mathrm{~mm}$. The highest velocity is $0.03 \mathrm{~m} / \mathrm{s}$. The shake table test machine is shown in Figure 2. The laminar box is positioned on the shake table as presented in Figure 3.
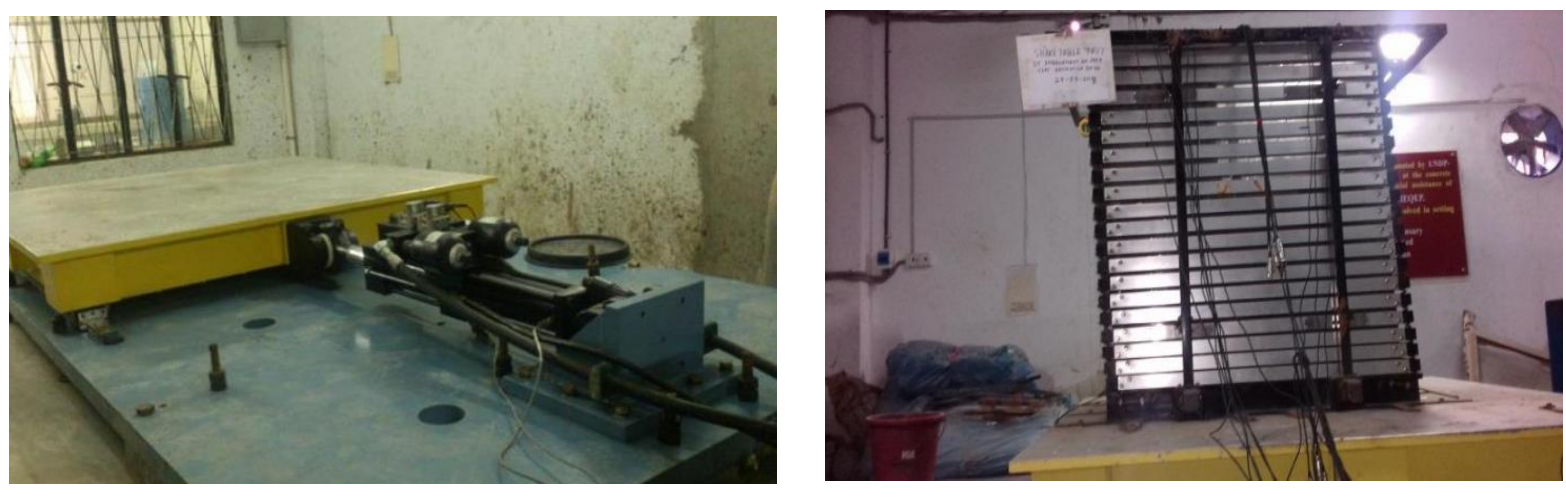

Figure 2. Shake table test apparatus

Figure 3. Laminar box mounted on shake table

A Laminar box was constructed on the shake table apparatus to reduce boundary effects wherever possible. The Laminar box neither resists nor promotes soil displacement to 
accommodate the movement of soil. The laminar shear box has 24 hollow aluminum layers of frames developed at Bangladesh University of Engineering and Technology (BUET). Every layer consists of an internal structure with internal dimensions of $915 \mathrm{~mm} \times 1220 \mathrm{~mm}$ $\times 1220 \mathrm{~mm}$.

A Laminar box was constructed on the shake table apparatus to reduce boundary effects wherever possible. The Laminar box neither resists nor promotes soil displacement to accommodate the movement of soil. The laminar shear box has 24 hollow aluminum layers of frames developed at BUET. Every layer consists of an internal structure with internal dimensions of $915 \mathrm{~mm} \times 1220 \mathrm{~mm} \times 1220 \mathrm{~mm}$. Sylhet sand was used as the backfill material that was available locally. The unified soil classification system classified the sand as poorly graded sand (S.P). The maximum and minimum dry densities were $18 \mathrm{KN} / \mathrm{m}^{3}$ and 16 $\mathrm{KN} / \mathrm{m}^{3} \mathrm{~m} 3$, respectively. The specific gravity of the sand particles was 2.34 . The relative density of sand was $60 \%$. The soft clay soil in Dhaka was used in this research work. The liquid limit and water content of this soil sample were found at $40 \%$ and $23 \%$ respectively. The soil sample used was prepared, by using $50 \%$ of water content (1.25 times of liquid limit). Cohesion was obtained by $14.8 \mathrm{KN} / \mathrm{m}^{2}$ and friction was obtained by 1.0 from the direct shear test. The water content of the soil sample was $14 \%$, and the unconfined compressive strength $\left(\mathrm{q}_{\mathrm{u}}\right)$ was $19 \mathrm{kPa}$, after the loading had been done. The thickness of the clay layer in the soil sample was $6 \mathrm{~m}$. Reconstituted soil sample preparation was displayed in Figure 4. Figure 5 illustrates the schematic diagram of the test configuration.
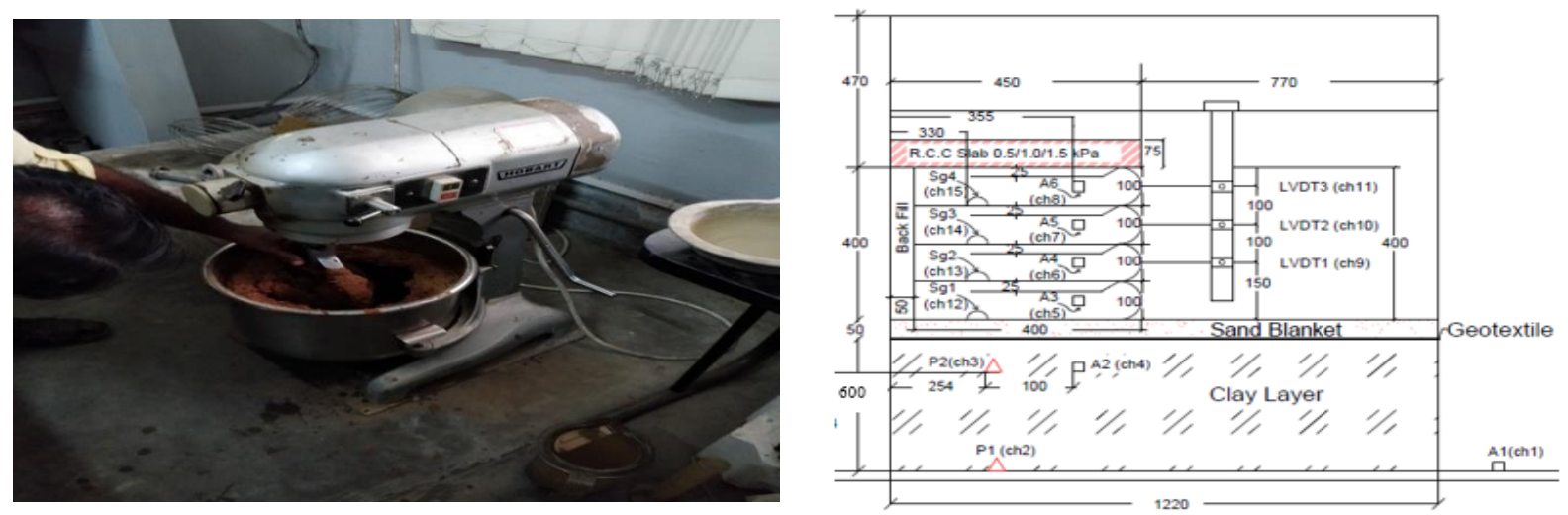

Figure 4. Preparation of clay layer

Figure 5. Schematic illustration of shake table test

\subsection{Testing Procedure}

The dimension of the laminar box was $1220 \mathrm{~mm}$ deep, and the size of the plan area was $915 \mathrm{~mm} \times 1220 \mathrm{~mm}$. In lifts of equal height, the model was constructed while 
reinforcing each lift with a layer of woven geotextile. To measure pore water pressure, two pore water sensors (P1 and P2) were placed as shown in Figure 5. Besides this, 6 acceleration sensors (A1, A2, A3, A4, A5, and A6) were placed on different points of the model, to measure acceleration. A1 and A2 sensors were placed in clay soil layers. Three displacement sensors (LVDT1, LVDT2, and LVDT3), were placed on different locations of the model to measure the displacement of the embankment. Table 1 shows the test sequence.

Table 1. Test Sequence

\begin{tabular}{ccccc}
\hline Test Name & $\begin{array}{c}\text { Acceleration } \\
\mathrm{a}_{\max (\mathrm{g})}\end{array}$ & Frequency Hz & $\begin{array}{c}\text { Relative density } \\
(\%)\end{array}$ & Surcharge (kg) \\
\hline FT1 & 0.1 & 1 & 60 & 19 \\
FT2 & 0.1 & 3 & 60 & 19 \\
FT3 & 0.1 & 5 & 60 & 19 \\
FT4 & 0.1 & 10 & 60 & 19 \\
FT5 & 0.1 & 12 & 60 & 19 \\
FT6 & 0.1 & 15 & 60 & 19 \\
\hline
\end{tabular}

\section{Results and Discussion}

The total number of 100 shaking table tests were conducted for this research. In this section, 6 shake table tests were described among the 100 shaking tests to evaluate the seismic response of the model retaining wall. The chosen base accelerations for this research were $0.1 \mathrm{~g}, 0.2 \mathrm{~g}, 0.3 \mathrm{~g}, 0.4 \mathrm{~g}$, and $0.5 \mathrm{~g}$ respectively. The natural frequency in this shake table test was determined to be $16 \mathrm{~Hz}$. Therefore, input frequency should be less than the natural frequency of the model. The Input frequencies were $1 \mathrm{~Hz}, 3 \mathrm{~Hz}, 5 \mathrm{~Hz}, 10 \mathrm{~Hz}, 12 \mathrm{~Hz}$ and $15 \mathrm{~Hz}$ respectively. The surcharge pressures selected for this study were $19 \mathrm{~kg}, 34 \mathrm{~kg}$, and $49 \mathrm{~kg}$.

A total number of 470 layers of soft clay soil were also presented in the GIS interface map. The Standard Penetration Test (SPT) zonation map was prepared based on SPT N value. The SPT zone map has four sub sections. The lower range of SPT zonation map is 1 to 2 and the higher range is greater than 5 . The $\mathrm{N}$ value is less than five, showing the existence of soft clay content of that area. This influences the dynamic behaviours of the embankment, (Hore et al., 2019). From the map (figure 6), the green colour shows the SPT value between 1 to 2 . The capital of Bangladesh, Dhaka, is occupied with soft clay zone containing SPT value 1 to 2. The output result was the dynamic behaviour like acceleration amplification, displacement and pore water pressure. This was shown in the contour map and the graph. The research 
showed that dynamic behaviour of the soil depends on the soil standard penetration test result. The zonation map using Standard Penetration Test $(\mathrm{N})$ value was shown in Figure 6.

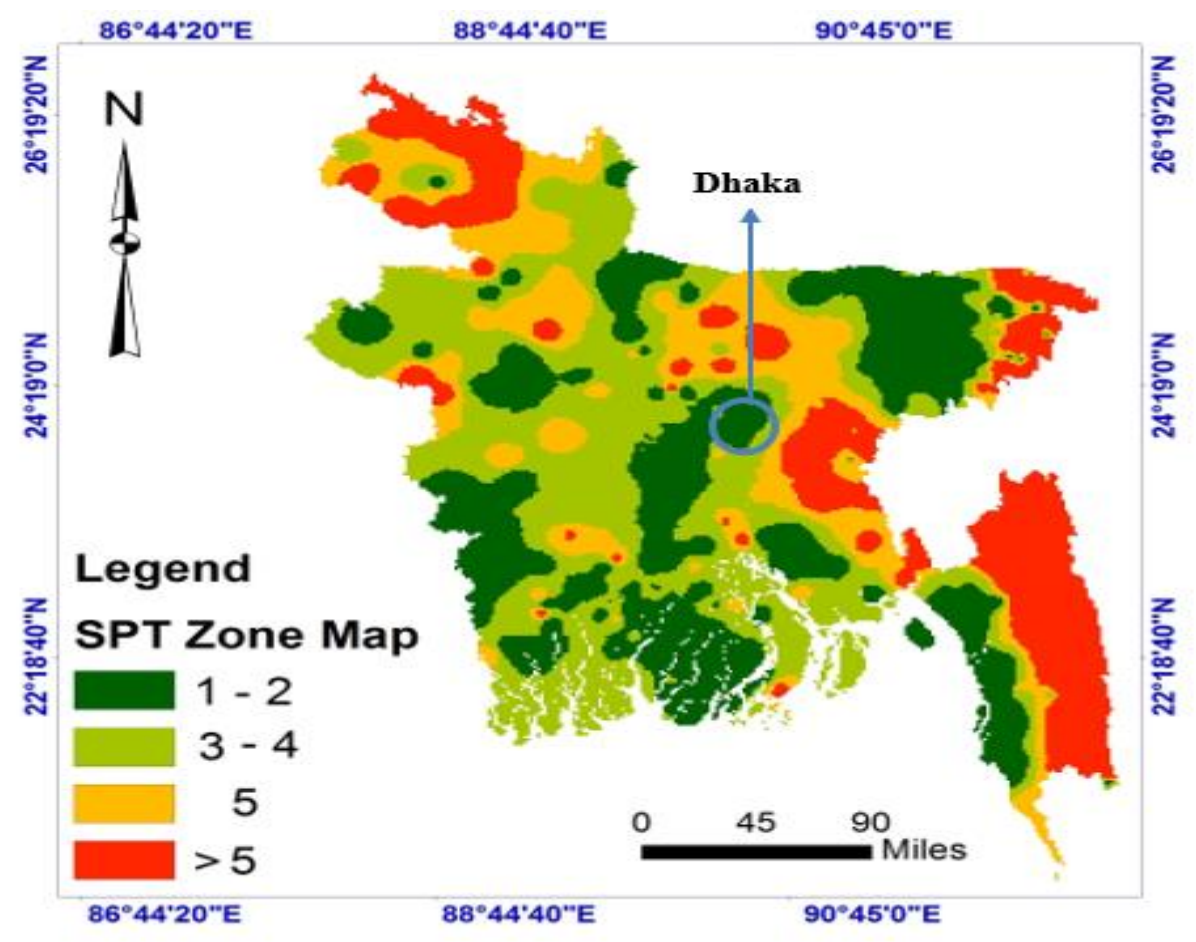

Figure 6. Zonation map using Standard Penetration Test (SPT)

\subsection{Acceleration Response}

The dynamic parameters for acceleration amplification response were FT1, FT2, FT 3, FT4, FT5, FT6 with frequencies of $1 \mathrm{~Hz}, 3 \mathrm{~Hz}, 5 \mathrm{~Hz}, 10 \mathrm{~Hz}, 12 \mathrm{~Hz}$ and $15 \mathrm{~Hz}$ respectively. These were conducted at $0.1 \mathrm{~g}$ base acceleration and $19 \mathrm{~kg}$ surcharge pressure, as shown in figure 7. Figure 8 shows the acceleration amplification variation with respect to frequency without clay layers. Figure 7 displays the two sensors in the clay soil sample layer for the different frequencies of $1 \mathrm{~Hz}, 3 \mathrm{~Hz}, 5 \mathrm{~Hz}, 10 \mathrm{~Hz}, 12 \mathrm{~Hz}$ and $15 \mathrm{~Hz}$ from FT1, FT2, FT3, FT4, FT5, and FT6 model tests respectively. From the figure, it can be seen that acceleration amplitude decreases, with increasing normalized elevation,for the frequency of 1 Hz. Conversely, acceleration amplitude increases with rise innormalized elevation for other frequencies. The previous figure shows that acceleration amplification and frequency are not directly proportional. In fact, within the range of tests conducted, accelerations were amplified less for $1 \mathrm{~Hz}, 3 \mathrm{~Hz}$, and $5 \mathrm{~Hz}$ and more for $10 \mathrm{~Hz}$ and $12 \mathrm{~Hz}$ compared to that of 15 $\mathrm{Hz}$ at all elevations. Moreover, accelerations at normalized elevations of 0.25, 0.5, 075, and 1 
were amplified closer or slightly more than 1 for the frequency of $1 \mathrm{~Hz}$. The differences in acceleration amplification for various frequencies were increased with increase in wall height. At a normalized height of 1 , for $1 \mathrm{~Hz}, 3 \mathrm{~Hz}, 5 \mathrm{~Hz}, 10 \mathrm{~Hz}, 12 \mathrm{~Hz}$, and $15 \mathrm{~Hz}$, the values for acceleration amplification were 1.04, 1.24, 1.46, 3.26, 2.47, and 1.80 respectively. These test results of acceleration are partially similar to the (Cai et al., 2019; Fleming et al., 2016; Hore et al., 2020).

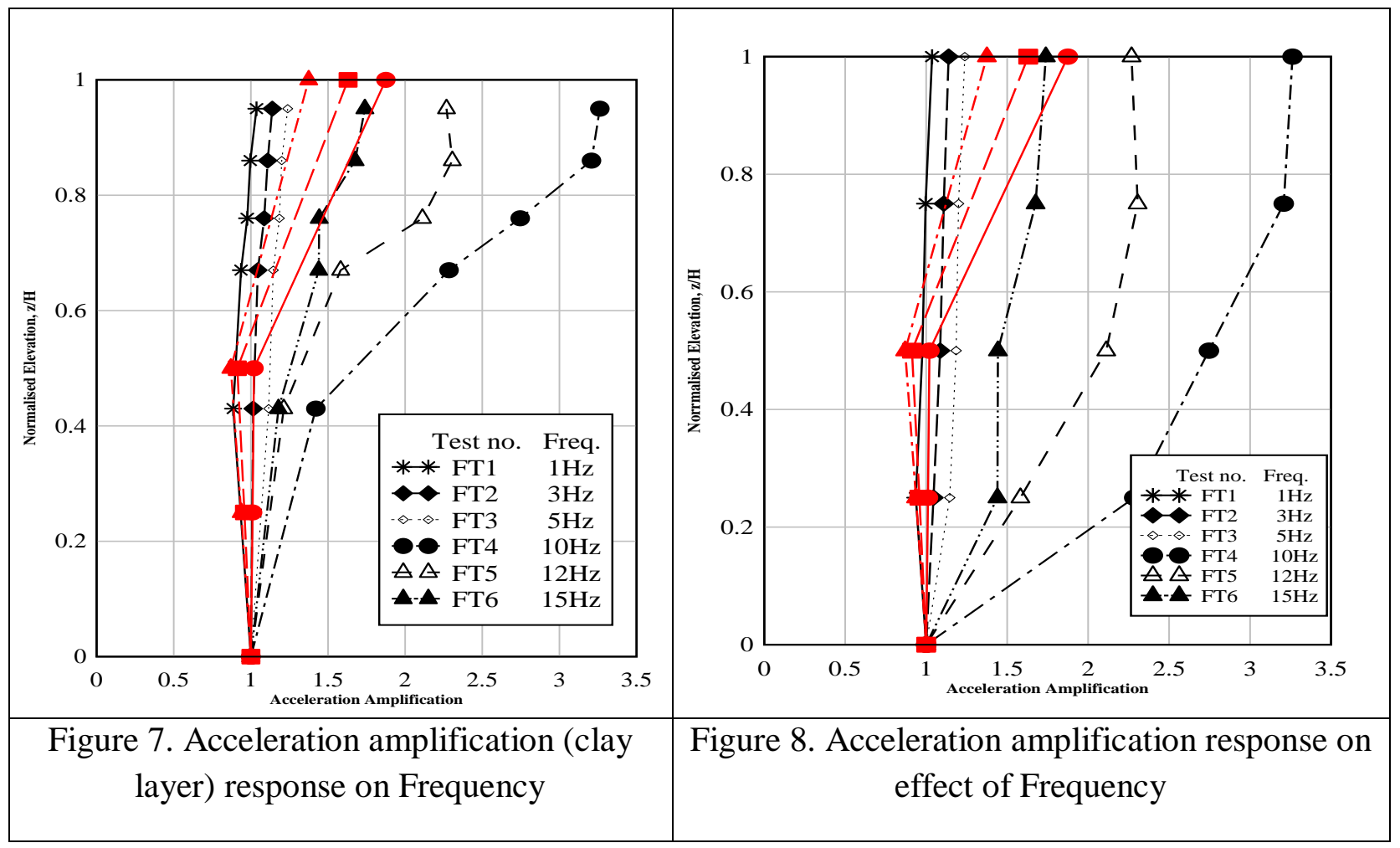

\subsection{Face Displacement Response}

Figure 9 shows the displacement profiles observed for tests FT1, FT2, FT3, FT4, FT5, and FT6 with frequencies $1 \mathrm{~Hz}, 3 \mathrm{~Hz}, 5 \mathrm{~Hz}, 10 \mathrm{~Hz}, 12 \mathrm{~Hz}$ and $15 \mathrm{~Hz}$ respectively. It was observed that at the highest elevation $(\mathrm{z} / \mathrm{H}=0.875)$, the displacement was maximum. The highest normalized displacement of $2.01 \%$ was observed for $12 \mathrm{~Hz}$ frequency. The corresponding values for the frequencies of magnitudes $1 \mathrm{~Hz}, 3 \mathrm{~Hz}, 5 \mathrm{~Hz}, 10 \mathrm{~Hz}$ and $15 \mathrm{~Hz}$ were $0.02 \%, 1.99 \%, 2.05 \%, 2.01 \%$ and $1.93 \%$ respectively. These test results of face displacement response are partially similar to the (Krishna \& Latha, 2007; Srinivasan et al., 2016; Suzuki et al., 2015). 


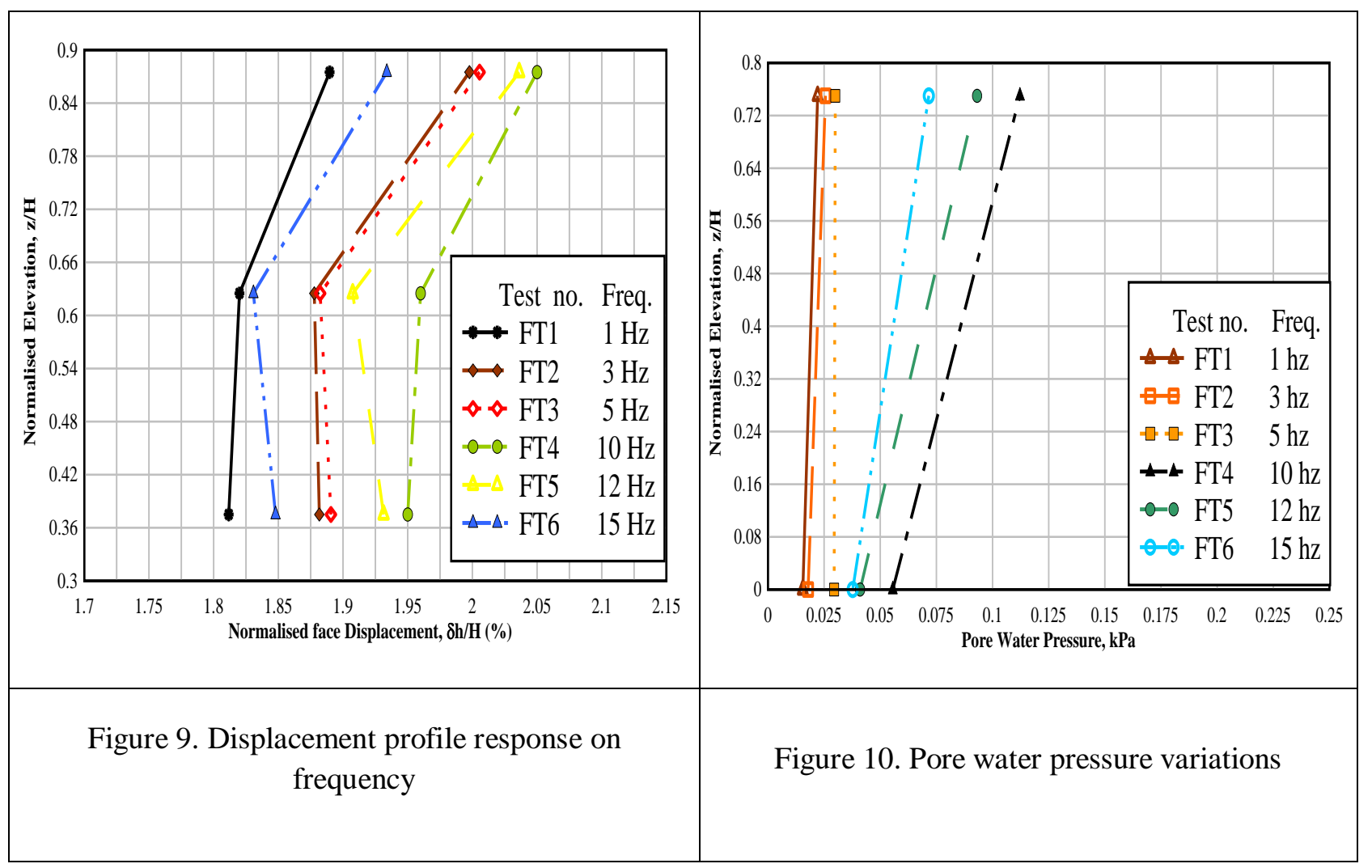

\subsection{Variations of Pore Water Pressure}

Figure 10 shows the effect of frequency for fixed base acceleration $(0.1 \mathrm{~g})$ and surcharge $(19 \mathrm{~kg})$ on acceleration amplification, strain and pore water pressures. The variations were for tests FT1, FT2, FT3, FT4, FT5 and FT6 with the Frequency of $1 \mathrm{~Hz}, 3$ $\mathrm{Hz}, 5 \mathrm{~Hz}, 10 \mathrm{~Hz}, 12 \mathrm{~Hz}$ and $15 \mathrm{~Hz}$ respectively for $0.1 \mathrm{~g}$ base accelerations and $19 \mathrm{~kg}$ surcharge. The pore water pressures increase with increasing elevation. The pore water pressure was $0.07 \mathrm{kPa}$ at frequency of $10 \mathrm{~Hz}$. The maximum pore water pressure for model tests FT1, FT2, FT3, FT4, FT5, and FT6 were $0.02 \mathrm{kPa}, 0.03 \mathrm{kPa}, 0.03 \mathrm{kPa}, 0.11 \mathrm{kPa}, 0.09$ $\mathrm{kPa}$, and $0.07 \mathrm{kPa}$ respectively. Figure 11 shows the contour map (PLAXIS 3D output results) of acceleration, displacement, and pore water pressure response. 


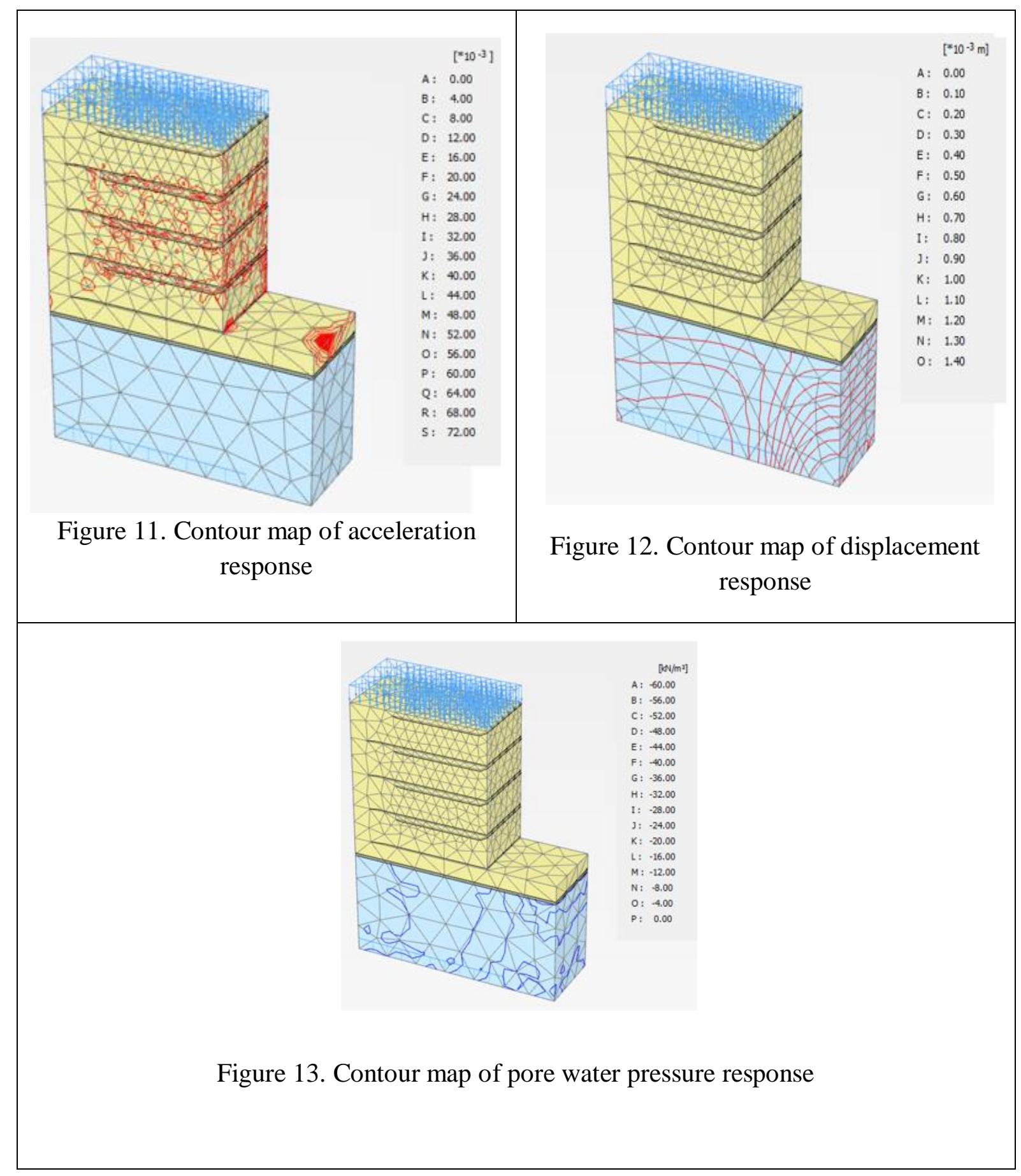

This research discusses the results found from 6 different shake table tests from 100 combinations, on the embankment with soft clay models. The acceleration of thistest varied from time to time. The acceleration of the test were as follows: $0.1 \mathrm{~g}, 0.2 \mathrm{~g}, 0.3 \mathrm{~g}, 0.4 \mathrm{~g}$ and $0.5 \mathrm{~g}$. During the shake table test, the natural frequency was the first calculated and its test result was $16 \mathrm{~Hz}$. Therefore, the other frequencies should be less than the natural frequency. The other frequencies were $1 \mathrm{~Hz}, 3 \mathrm{~Hz}, 5 \mathrm{~Hz}, 10 \mathrm{~Hz}, 12 \mathrm{~Hz}$ and $15 \mathrm{~Hz}$. This means that the 
frequencies ranged from $1 \mathrm{~Hz}$ to $15 \mathrm{~Hz}$. During the shake table test, surcharge pressure varied for each test. Changing the surcharge pressure and wrap faced embankment was newly created. The surcharge pressures were $19 \mathrm{~kg}, 34 \mathrm{~kg}$ and $49 \mathrm{~kg}$. After conducting the unconfined compressive test, the result was $20 \mathrm{kPa}$. The wrap faced embankment height was $4 \mathrm{~m}$ and therefore, the model was developed. The length (L) of the geotextile reinforcement was $3.75 \mathrm{~m}$. Also, 20 cycles of sinusoidal shakes were subjected to the model wall. All of the present model walls were later constructed with sand placed on the same medium to loosen density. The sand embankment properties were as follows: i) average unit weight ii) the relative density which were $18 \mathrm{KN} / \mathrm{m} 3$ and $60 \%$ respectively. These results obtained were similar to that of other researcher swho only used sand embankment without clay soil (Eric et al., 2013; Goktepe et al., 2019; Srilatha et al., 2013). The cyclic behaviour of the soft clay has been analysed based on the different input frequency.

The face deformations were high for low-frequency shaking, low for surcharge pressures and high for base accelerations. The pore water pressures were observed to increase with a rise in base motion frequency. Three contour maps were drawn to investigate the acceleration amplification, deformation, and pore water pressure with respect to frequency response. These maps also showed dynamic parameters such as acceleration amplification, deformation, and pore water pressure representations of the soft soil. These results were very important for observing the dynamic behaviour of wrap faced soil retaining walls on the soft clay layer. This can be applied to improve incorporating dynamic loading, considering the design specification of this type of retaining wall (Railway and Road embankment).

\section{Conclusion}

The shake table test on wrap faced embankment on the clay soil foundation, is a new form of test. The lower range of SPT zonation map is 1 to 2 and the maximum range is greater than 5. In Bangladesh, embankment on soft clay soil plays a very vital role in seismic perspective. Therefore, the research opportunity of this area will bring about an upgrade to seismic design specifications. From the test results, it was discovered that face deformation increases with rise in elevation. At high elevations and frequencies, pore water pressure is also high. These test results are beneficial in understanding the relative performance of the wrap faced embankment, which is the indicative direction to the design process of embankment. 


\section{Conflict of Interest}

The authors declare that there is no conflict of interest with any financial, personal, or other relationships with other people or organizations related to the material discussed in the article.

\section{References}

Al zaman, M. A., \& Jahan Monira, N. (2017). A Study of Earthquakes in Bangladesh and the Data Analysis of the Earthquakes that were generated In Bangladesh and Its' Very Close Regions for the Last Forty Years (1976-2016). Journal of Geology \& Geophysics, 06(04), 6-10. https://doi.org/10.4172/2381-8719.1000300.

Alam, M. J., \& Islam, M. S. (2009). Geological Aspects of Soil Formation of Bangladesh. Conference: Bangladesh Geotechnical Conference 2009 (BGC-2009), Dhaka, Bongladesh.

Bazlar Rashid, M., Rashid, B., \& Islam, B. (2018). Structure and Lineaments of the Northwestern Part of Bangladesh and Evolution of the Barind Tract. American Journal of Earth Sciences, 5(3), 26-36.

Beskhyroun, S., Wegner, L. D., \& Sparling, B. F. (2011). Integral resonant control scheme for cancelling human-induced vibrations in light-weight pedestrian structures. Structural Control and Health Monitoring, May 2011, n/a-n/a. https://doi.org/10.1002/stc.

Bullock, Z., Dashti, S., Liel, A., Porter, K., \& Karimi, Z. (2019). This preprint is a PDF of a manuscript that has been accepted for. Earthquake Spectra (PREPRINT), 1-33. https://doi.org/10.1016/j.ssresearch.2016.09.015.

Cai, W., Yu, B., \& Kaewunruen, S. (2019). Shaking table tests of suspended structures equipped with viscous dampers. Applied Sciences (Switzerland), 9(13). https://doi.org/10.3390/app9132616.

Çelebi, E., Göktepe, F., \& Omid, A. J. (2019). Seismic soil response of scaled geotechnical test model on small shaking table. Arabian Journal of Geosciences, 12(2). https://doi.org/10.1007/s12517-018-4197-8.

Edinçliler, A., \& Toksoy, Y. S. (2017). Shake table tests to measure the dynamic performance of geotextile-reinforced embankment. Periodica Polytechnica Civil Engineering, 61(4), 803-814. https://doi.org/10.3311/PPci.10540.

Eric, R., Moss, S., \& Crosariol, V. A. (2013). Scale Model Shake Table Testing of an Underground Tunnel Cross Section in Soft Clay. 29(4), 1413-1440. https://doi.org/10.1193/070611EQS162M.

Ering, P., \& Sivakumar Babu, G. L. (2020). Effect of spatial variability of earthquake ground motions on the reliability of road system. Soil Dynamics and Earthquake Engineering, 136(December 2019), 106207. https://doi.org/10.1016/j.soildyn.2020.106207.

Fleming, B. J., Eeri, M., Sritharan, S., \& Miller, G. A. (2016). Full-Scale Seismic Testing of Piles in Improved and Unimproved Soft Clay. 32(1), 239-265. 
https://doi.org/10.1193/012714EQS018M.

Goktepe, F., Celebi, E., \& Omid, A. J. (2019). Numerical and experimental study on scaled soil-structure model for small shaking table tests. Soil Dynamics and Earthquake Engineering, 119(August 2018), 308-319. https://doi.org/10.1016/j.soildyn.2019.01.016

Hamayoon, K., Morikawa, Y., Oka, R., \& Zhang, F. (2016). 3D dynamic finite element analyses and $1 \mathrm{~g}$ shaking table tests on seismic performance of existing group-pile foundation in partially improved grounds under dry condition. Soil Dynamics and Earthquake Engineering, 90, 196-210. https://doi.org/10.1016/j.soildyn.2016.08.032.

Haque, M. E., Sayem, H. M., \& Kamal, M. (2013). Assessment of Some Engineering Geological Aspects of the Sub-soil of Ganakbari, Dhaka, Bangladesh. Jahangirnagar University Environmental Bulletin, 2(September), 61-70. https://doi.org/10.3329/jueb.v2i0.16331.

Hassan, A., \& Pal, S. (2018). Effect of soil condition on seismic response of isolated base buildings. International Journal of Advanced Structural Engineering, 10(3), 249-261. https://doi.org/10.1007/s40091-018-0195-z.

He, T., \& Jiang, N. (2019). Substructure shake table test for equipment-adjacent structuresoil interaction based on the branch mode method. Structural Design of Tall and Special Buildings, 28(4), 1-19. https://doi.org/10.1002/tal.1573.

Helwany, S., Wu, J. T. H., Meinholz, P., Alizadeh, V., \& Ghaderi, R. (2017). Seismic Behavior of GRS Bridge Abutments with Concrete Block Facing: an Experimental Study. Transportation Infrastructure Geotechnology, 4(4), 85-105. https://doi.org/10.1007/s40515-017-0040-z.

Hore, R., Arefin, M. R., \& Ansary, M. A. (2019). Development of Zonation Map Based on Soft Clay for Bangladesh. Journal of Engineering, 10(1), 13-18.

Hore, R., Chakraborty, S., Shuvon, A. M., \& Ansary, M. A. (2020). Effect of Acceleration on Wrap Faced Reinforced Soil Retaining Wall on Soft Clay by Performing Shaking Table Test. 15, 1-11.

Krishna, A. M., \& Latha, G. M. (2007). Seismic response of wrap-faced reinforced soilretaining wall models using shaking table tests. Geosynthetics International, 14(6), 355364. https://doi.org/10.1680/gein.2007.14.6.355.

Kumar, V., Chopra, S., Choudhury, P., \& Kumar, D. (2020). Estimation of near surface attenuation parameter kappa $(\kappa)$ in Northwest and Northeast Himalaya region. Soil Dynamics and Earthquake Engineering, 136(September 2019), 106237. https://doi.org/10.1016/j.soildyn.2020.106237.

Latha, G., \& Krishna, A. (2006). Shaking table studies on reinforced soil retaining walls. Indian Geotechnical Journal, 36(4), 321-333.

Madhavi Latha, G., \& Manju, G. S. (2016). Seismic Response of Geocell Retaining Walls Through Shaking Table Tests. International Journal of Geosynthetics and Ground Engineering, 2(1), 1-15. https://doi.org/10.1007/s40891-016-0048-4.

Srilatha, N., Latha, G. M., \& Puttappa, C. G. (2013). Effect of frequency on seismic response of reinforced soil slopes in shaking table tests. Geotextiles and Geomembranes, 
36(September 2014), 27-32. https://doi.org/10.1016/j.geotexmem.2012.10.004.

Srinivasan, V., Srivastava, S., \& Ghosh, P. (2016). Optimization and Parametrical Investigation to Assess the Reconstitution of Different Types of Indian Sand Using Portable Travelling Pluviator. Geotechnical and Geological Engineering, 34(1), 59-73. https://doi.org/10.1007/s10706-015-9928-y.

Suzuki, M., Shimura, N., Fukumura, T., Yoneda, O., \& Tasaka, Y. (2015). Seismic performance of reinforced soil wall with untreated and cement-treated soils as backfill using a 1-g shaking table. Soils and Foundations, 55(3), 626-636. https://doi.org/10.1016/j.sandf.2015.04.013.

Xiao, M., Ledezma, M., \& Hartman, C. (2014). Shake table test to investigate seismic response of a slurry wall. Geotechnical Special Publication, 234 GSP, 1234-1243. https://doi.org/10.1061/9780784413272.120.

Yazdandoust, M. (2017). Investigation on the seismic performance of steel-strip reinforcedsoil retaining walls using shaking table test. Soil Dynamics and Earthquake Engineering, 97(November 2016), 216-232. https://doi.org/10.1016/j.soildyn.2017.03.011.

Ye, J., \& Jiang, L. (2018). Simplified analytical model and shaking table test validation for seismic analysis of mid-rise cold-formed steel composite shear wall building. Sustainability (Switzerland), 10(9). https://doi.org/10.3390/su10093188.

Zhou, Y., Wang, H., Wen, R., Ren, Y., \& Ji, K. (2020). Insights on nonlinear soil behavior and its variation with time at strong-motion stations during the Mw7.8 Kaikoura, New Zealand earthquake. Soil Dynamics and Earthquake Engineering, 136(29), 106215. https://doi.org/10.1016/j.soildyn.2020.106215. 